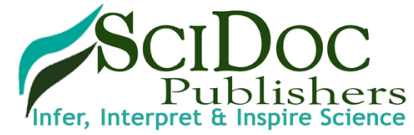

\section{Export Control Regulations in the United Arab Emirates - Comparative Analysis with the United Kingdom}

Research Article

Bashar H. Malkawi*

Dean and Professor of Law, University of Sharjah, United Arab Emirates.

Abstract

Governments across the world appreciate the need for checks on the transfer or exportation of commodities, information, software, and technology considered of strategic value. In order to control exports, countries rely on laws, treaties, international arrangements and other related instruments. In the current case, the UAE is largely dependent on Federal Law No. 12 of 2008 while the UK depends on the Export Control Act of 2002. It is established that the legislations enact amendments to reflect the dynamic nature of the state environment. However, the entry into international arrangements supports the view that the fight against trading in dual-use, military, or sensitive products require cooperative efforts from state parties in order to attain success. The current paper assesses export controls in the United Arab Emirates and the United Kingdom.

Keywords: Export Control; International Economic Law; Free Trade; United Arab Emirates; United Kingdom.

Abbreviations: UAE: United Arab Emirates; UNSC: United Nations Security Council; CWC: Chemical Weapons Convention; FANR: Federal Authority for Nuclear Regulation; WA: Wassenaar Arrangement; ZC: Zangger Committee; MTCR: Missile Technology Control Regime; MoD: Ministry of Defence; FCO: Foreign and Commonwealth Office; ECO: Export Control Organisation; AG: Australia Group; NSG: Nuclear Suppliers Group.

\section{Introduction}

Governments across the world appreciate the need for checks on the transfer or exportation of commodities, information, software, and technology considered of strategic value. Items are viewed as deserving of control if they touch on issues national security and defense. In some cases however, products that have critical economic value or border on foreign policy are put into the category of sensitive commodities that are controlled. For such reasons, extensive networks, laws and regulations are devised to ensure that the transfer or trade in sensitive/dual-use items is under scrutiny. Precisely, export controls are regulations on shipment and transfer of strategic/controlled items. In practice, noncompliance attracts severe penalties. Thus, parties which trade in such commodities must acquire licenses, and operate as specified by the existing guidelines. The current paper assesses export controls in the United Arab Emirates and the United Kingdom.

In order to control exports, countries rely on laws, treaties, inter- national arrangements and other related instruments. In the current case, the UAE is largely dependent on Federal Law No. 12 of 2008 while the UK depends on the Export Control Act of 2002. It is established that the legislations enact amendments to reflect the dynamic nature of the state environment. However, the entry into international arrangements supports the view that the fight against trading in dual-use, military, or sensitive products require cooperative efforts from state parties in order to attain success.

\section{Export Controls in the UAE}

The United Arab Emirates (UAE) has been late in as far as cooperating with the international community on the issue of Export Control. The UAE had the widest gap between commitment and compliance on nonproliferation export control [1]. Such checks reflect national restrictions that governments impose regarding the exportation of sensitive technologies and goods. In particular, focus is paid to dual-use goods or arms. It was not until 2007 that the UAE set in place a law to guide the export of such items. Stin-

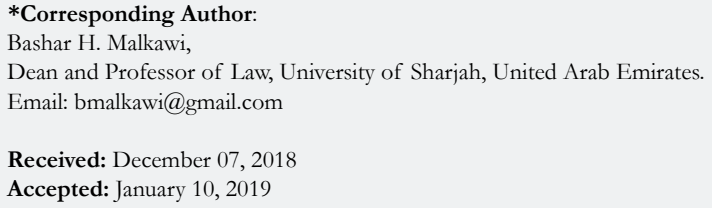

Copyright: Bashar H. Malkawi ${ }^{\circ}$ 2019. This is an open-access article distributed under the terms of the Creative Commons Attribution License, which permits unrestricted use, distribution and reproduction in any medium, provided the original author and source are credited. 
nett, Early, Horne and Karreth noted that the country lacked even an institutional framework to oversee the trade [2]. In the face of the prevailing circumstances, it was possible for other states to exploit the UAE by labeling it an illicit proliferation front. For example, Early remarked that owing to the existing gap, Iran was able to station intermediaries in the country for use in the acquisition of sensitive products yet it was facing sanctions at the international scene [2]. The recent commitments by the UAE have however signaled the country's commitment to the adoption of controls necessary for it to be allowed to carry on its nuclear energy project.

The obligations of the UAE to adopt an effective export control systems rests on the role played by the United Nations Security Council (UNSC) in its pursuit of encouraging voluntary commitment [3]. Bergenäs noted that in 2004, the United Nations passed Resolution 1540 paving the way for the creation of a universal obligation that binds all states to establish export control frameworks [4]. In 2008, the UNSC barred countries from trading in sensitive items with Iran. In 2008, the UAE committed to the Nuclear Suppliers Group's Export Guidelines on sensitive materials. In this regard, the country was committing to contribute towards efforts that improve peace and international security by limiting the proliferation of arms or material for the manufacture of harmful products.

When evaluating the nation's export control system, reference is made to three major dimensions: the legal framework, the level of institutionalization and implementation. The degree of the legal development in a state's control organization is assessed based on the comprehensiveness of the export control laws in terms of how they restrict the flow of commodities, transaction types that are disallowed, the type of body set up to enforce the guidelines and the punitive measures attached to the violation of the law [5]. Regarding the institutional framework, the level of bureaucratization of exports is put into perspective. A country is said to be committed if it has institutions that monitor and regulate international trade that goes through its borders. In addition, the presence of institutions capable of evaluating and permitting trade in controlled goods and entities with the capacity to enforce laws is critical. Besides establishing such provisions, states must demonstrate consistency in the implementation of their export control regulations.

Establishing close cooperation between and among governmental authorities and commercial sectors is also an essential requirement in the functioning of the control systems [6]. In this regard, governments need to publicize and clarify their export control objectives. When implementing the export control measures, ensuring that fairness, transparency and integrity prevail is significant. Such factors are needed to ensure that the private sector is wooed into supporting the fight against illicit trade.

A high degree of technical expertise is also a basic requirement in the establishment of effective export control mechanisms [7]. Similarly, it is critical that tacit knowledge on design is gained. Based on this, staff from implementing agencies should be trained on how to carry out their duties professionally. In particular, customs agents need effective training so that they can more easily identify illicit goods. The personnel also need to spot dual-use or sensitive goods. Licensing officials also need training on unique products. In order to attain the objective, international cooperation is essential. However, efforts should be directed towards developing an effective local system.

\section{UAE Export Control Framework}

The UAE has the challenge of establishing an effective export control system that is in line with international standards. Under the confederation structure of the UAE, each of its seven Emirates has the authority to run its customs agencies autonomously [1]. It is only recently (2003), that the national government of the UAE set up the Federal Customs Authority. Running a decentralized system of governance presents challenges that must be overcome when handling a national export control framework. The first all-inclusive law to guide the exports control system was established in 2007 [1]. The details of the new provisions reflect an ambitious attempt by the country to strike a grip on the control of exports. However, concerns arise regarding the institutionalization and implementation of the new law.

In the current section, special attention is on the legal premises, institutionalization and execution of export control in UAE. It is noted that the UAE's Federal Law No. 13 of 2007 sets in place a comprehensive set of controls that govern exporting, re-exporting, transshipment and transit of dual-use/sensitive goods across territories as observed by Early. The enactment also extends to the free trade zones of UAE in explicit terms. The provisions also cover brokerage-involving transactions on restricted products and intangible items such as blueprints and software. The intention is to protect sensitive technology from proliferation and abuse. The law also accords Emirati authorities wide discretion on its role in preventing transactions that are likely to contribute to the proliferation of sensitive products.

Violations of the above law can result in severe penalties [4]. The punitive measures are both criminal and administrative which encompass heavy fines and even jail terms. The export control legislation provides a wide but technical foundation that is useful in controlling exports. Under the provisions of the law, the emiratelevel agencies are required to work alongside federal ministries when enforcing the requirements. By extending the applicability of the legislation to cover the free trade zones and brokerage transactions on restricted goods, the law responds to the vulnerabilities which were previously exploited by architects of proliferation. Whereas Federal Law No. 13 and subsequent legislation established broad foundations for controlling exports, they failed to address issues of institutionalization and implementation [1]. Apparently, the gray areas were to be addressed by a high-level committee to be formed later. Given that many practical regulations were not developed, the implementation of the law was bound to encounter many challenges.

In 2009, the council of ministers from the UAE launched the Commission on Commodities Subject Import and Export Controls [6]. The composition of the body took into consideration federal ministries involved in export control matters. The minister of foreign affairs headed the commission. Given the weighty mandate of institutionalizing the country's export control, and developing the licensing system required to regulate trading in restricted products, little progress was made in its absence. Thus at its inception, the expectation was that the UAE was progressing on the control of exports framework. With institutionalization, the export control framework would signal the emergence 
of standard procedures and rules to oversee the management of exports from the country. Although each ministry involved in the export business is represented in the commission, a clear framework does not exist to delineate the responsibilities of the participants. In addition, no clear plan exists on the coordination of emirate-level agencies regarding the actual control or enforcement of export controls.

Ultimately, the development of an efficient coordination model among the stakeholders involved is a major challenge that must be overcome for the control system to work properly. Beyond the responsibility, the implementation commission has encountered concerns regarding the creation of institutional as well as individual competencies across the various cadres of the nation's export control system [6]. Thus, those charged with the task of regulating exports lack the capacity to do so. Thus, the UAE is obliged to roll out extensive training measures to enhance its capacity to control exports effectively.

Although the authorities at the Emirates claim that many actions have been launched to lower illicit trade, the enforcements have not followed a structured approach, but rather, they have been based on ad hoc responses. Citing the Wall Street Journal, Early indicated that officials from the country had closed forty Iranian entities which operated in Dubai whose activities violated the law [1]. UAE also claimed that it had obstructed more than ten proliferation-sensitive activities to Iran. In particular, Dubai had worked tirelessly to train its frontline staff (custom officers) on how to identify and handle proliferation cases. The enforcement efforts demonstrate that the Emirates state is committed towards defeating illicit trade through the establishment of an effective export control framework.

Most of the events revolving around the law adopted by the UAE government have resulted from information emanating from foreign governments, which the GCC state enjoys cordial ties [4]. Nevertheless, the ad hoc approach to the enforcement of the law is reflective of the idea that the country has much to do if it is to accomplish the mission of eradicating proliferation. In particular, UAE needs to improve on its capacity to identify dual-usage items. Thus, the inadequacy of the country's institutions is an obstacle in establishing an effective export control system. Creating a licensing institution that has the capacity to control exports and coordinate the enforcement of the law would help in addressing the issue rather than relying on impromptu responses. For the UAE to be deemed an elite export control destination, it must consider fostering a culture of prevention rather than punishing violators within its boundaries.

Consequently, one of the primary areas that needs urgent attention is an outreach commercial sector which is regulated by export controls. It is noted that the Emirate governments have not done enough to publicize export control guidelines [4]. It is also surprising that the translated versions of the control provisions are not available publicly on the federal government's official electronic platform. It has also emerged that the UAE has set aside insufficient resources to educating the commercial sector on the aspects of compliance or non-compliance. It is also apparent that transparency is a concern given that the enforcement of the law is questionable. Another issue is that the government has never publicized the individuals/companies that have been penalized so far, nor has it specified the punishments doled out. In the West, such as in the United States and the UK, 'naming and shaming' is a common strategy used to deter violators.

Within the UAE, firms are deemed compliant with the export control laws when they satisfy the following conditions as observed by Horner [6]. First, organizations need to be aware of the country's export control framework, each entity understands all requirements on compliance with UAE controls, and the anticipated costs attributable to non-compliance outweigh violation risks. In addition, stiff penalties and perceptions of potential violators seem to play a role in the country's export controls system.

\section{Review of Selected Articles}

Within a year of its enactment, the Federal Law was amended in 2008, paving the way for the Federal Law No. 12 of 2008. In total, 14 amendments were attached. Under Article 1, the terms are defined. For Articles 2-7, the general provisions are laid out. The next eight articles document prohibitions while the sixth article outlines the penalties. Articles 17 through 22 comprise the closing provisions. Based on the law, the offenses established are comprehensive and compliant with the UNSC Resolution 1540. Below are selected quotes from the law.

Article 2 states, "Without prejudice to the competences of the authorities concerned, and with consideration to the stipulations of the international agreements adhered by the State or ratified by it, the competent authorities shall be entitled to ban or restrict the importation or exportation or re-exportation of any commodity or transiting or provisional shipping of commodities, or confining all that to one official authority in the State, in instances where commodity constitutes a hazard to public safety or public health ..." [8].

From the above article, it is apparent that the UAE accords state authorities the power to control items that enter or leave the country. The wide discretion borders on granting the concerned agencies the power to decide the commodities that pose a danger to the safety of the citizens. This article has closeness with the 'Catch-all Controls' in the UK which also permits authorities to evaluate goods and determine if they pose a risk to the country [9].

It is also acknowledged that the article allows the UAE to work with international agencies/bodies on the fight against proliferation or sale of dangerous items. After the ratification of treaties or international agreements, such pacts are binding, and signatories are expected to comply. The same applies to the UK which is a leading member in many international arrangements aimed at controlling the exportation of dual-use or military goods. For instance, the subscription to the ideas of the Wassenaar Arrangement demonstrates the commitment that the UK attaches to its international obligations in control exports.

Article 4 states, "The competent authority shall decide on the license application for importation and exportation submitted to it with regard to the commodities comprised in the provisions of Article 2 of this law within a period of 15 working days at most as from the data of the presentation of the application."

From the above article, it is apparent that the UAE, just like the UK, has established an agency to lead the licensing exercise of 
entities or persons interested in engaging in trading of sensitive items. In particular, dealers in sensitive or dual-use goods must seek approval from the relevant authorities before being granted the permission to handle such items.

Shifting attention to Article 8, the law states, "Exporting or re-exporting of strategic commodities specified in the list of strategic commodities is prohibited." The article also covers publication and distribution of technology deemed to be useful in the production of dangerous items. Another aspect that is covered under the article relates to the shipment of such products.

Article 8(2) further clarifies the issue of exporting strategic goods. "No person shall be allowed to export, re-export any commodity not included in the attached list here to, ship it provisionally, or allow it to enter in transit or get out of the State any document pertaining to any technology registered there on, or stored or embodied therein, or publish or divulge any technology, and such in the following two instances: Should he be notified by the Committee that the commodities or technology will or may be used in whole or in part in a related activity. Should the person know that the commodity or technology will or may be used in whole or in part in a related activity." The law directly relates to the UK laws on technology regulation which put stringent guidelines on the importation and distribution of such items [10].

Article 15 of the UAE law also presents significant clauses useful in fighting against illicit exports. The article states, "it shall be prohibited for any person to publish, transfer or reveal any information or documents related to the strategic commodities submitted to the Committee pursuant to the provisions of the present title unless by virtue of a prior written approval from the President of the Committee, except for the following cases.

a) Where the disclosure of the information occurs in response to the request of the judicial authorities in the State.

b) In the event of a decision issued by the Cabinet enabling a foreign government to investigate a foreigner in the country thereof or to try him for a crime committed on the territory of the said state, and such under specified conditions."

\section{Control Measures: International Arrangements}

In a bid to control exports into the country, the UAE's system has expanded considerably. For instance, the checks now include brokering, financial services, technology and imports. Under the UN's guidelines, four attributes are reflective of a system that has the capacity to reign on illicit exports [1]. The first aspect is having a comprehensive regulatory and legal framework. Secondly, establishing licensing practices and procedures to guide the movement of dual-use items and technology is propagated. Thirdly, such a system must demonstrate robustness in enforcing and maintaining integrity in the licensing system, risk detection, investigations and prosecution of cases. Conducting industry partnerships and outreach awareness to promote voluntary compliance was deemed essential.

In order to enhance its capacity in export controls, the UAE has entered deals and pacts at the international level. It is noted the country has ratified a range of initiatives and treaties which influence the strategic control of foreign trade. The pacts signed relate to nuclear, biological and chemical, missile, terrorism and proliferation [6]. Regarding terrorism, the UAE is a party to many initiatives such as the Container Initiative, the Security Freight Initiative, and the Megaports Initiative. On proliferation, the UAE is a participant in many activities aimed at countering the supply of goods used to advance adverse engagements. For instance, the country has openly approved the Proliferation Security Initiative. It is noted that the UAE is a member of the Comprehensive Nuclear-Test-Ban Treaty and the Non-Proliferation Treaty, which bring together states, united against nuclear weapons development. In ratifying of the Chemical Weapons Convention (CWC) in 2000, UAE supports laws aimed at controlling the use of chemical and biological warfare. Thus, apart from the local laws, the UAE has domesticated international initiatives and treaties in its bid to contribute towards the control of exports.

However, it is surprising that the UAE is not a party to the Australia Group (AG) or the Nuclear Suppliers Group (NSG), entities focused on collating and publishing dual-use product lists viewed as sensitive [6]. One of the reasons advanced to account for this discrepancy is that the UAE is seeking to incorporate the lists into its strategy before seeking membership. However, the country has supported the implementation of import and export checks on nuclear related technology and equipment as outlined under the NSG policy. However, the compliance to AG requirements remains unclear.

\section{Control Lists}

Licensing systems entail collation and publication of lists of products that require licenses [9]. Export trade control offenses are thus defined based on licensing requirements breaches as documented in the items on the lists. The country of UAE has not yet published a control list despite reference to a list being made in UAE's export control law. Such a list is required before the full implementation and enforcement of the legislation.

The delay in publishing the list remains hidden because they have not been publicized [1]. However, the absence might be explained by the indecision regarding the inclusion of multilateral listed items or to consolidate and correlate them. Crucially, the lack of a license application platform is also a contributing factor. Indirectly, it is observed that the UAE has adopted the list by the NSG and $A G$, having ratified the BTWC and the CWC.

The fact that the law on export control was amended within a year of its adoption highlights the rash nature surrounding the development of the law. The intention was to control the amount of pressure that was coming from the United States.

\section{Institutional Development}

Within the UAE, it is notable that the structure is highly fragmented as the federal and Emirates operate a decentralized system of governance. Every Emirate has its own distinct customs body which operates under the Federal Customs Authority. Despite all Emirates subscribing to the GCC guidelines on customs, reporting as well as declaration of exports varies from one Emirate to another and to the free trade zones.

Several entities also function within the Emirates in the bid to control exports from the UAE. The agencies are in charge issuing licenses. The efforts to reign on exports dates back to 2006 
following the formation of the UAE Counter proliferation Task Force which was to participate in talks with the United States. After one year, the Executive Committee on Commodity Control Procedure was formed to oversight and manage the country's export procedures [1]. Within a month, the Executive Committee on Commodity Control Procedures and the Counter proliferation Task Force merged with the aim of protecting the country from exploitation. In 2009, the Council of Ministers released a decree paving the way for the formation of the Committee for Goods and Materials Subject to Import and Export Control. The body was to take charge of many responsibilities such as strategic planning, coordination and cooperation, preparation of procedures, and developing implementation regulations. Thus, the committee assumed both licensing and coordination roles.

Regarding nuclear controls, the establishment of Federal Law No. 6 of 2009 is illustrative of the export environment in the UAE. The law relates to the use of nuclear energy for peaceful purposes. It also stipulates measures to be taken against violators. Besides, the law led to the establishment of the Federal Authority for Nuclear Regulation (FANR).

Under Article 25, FANR is responsible for the regulation of materials entering or exiting the country. However, Law No. 13 of 2007 supersedes such provisions since the former must be in line with the latter's. Radioactive substances, nuclear fuel, and related material fall under this legislation.

The executive officer of FANR has the power to issue licenses both for import and export. The same applies to transit and the transshipment of dual-use/controlled goods [1]. The authority is responsible for controlling the licensing of nuclear-related issues. In the UK, the issue is labeled as rating. The agency also provides rating services on items seized on the suspicion of violating export controls [11]. The UAE has demonstrated its willingness to cooperate on stamping out the problem of exporting harmful products. In particular, the UAE is concerned with activities in Iran regarding the shipment of sensitive goods.

The UNSC sanctions are meant to pressure non-compliant states into changing their approaches. Under Article 25 of the UN Charter, members of the international body are obliged to execute the decisions of the UNSC [4]. Only states can carry out the agreements within domestic circles. The implication is that each country must domesticate international pacts. In practice, at any one given moment, it is always possible to find that some states have not localized international obligations. The UAE lacks legislation that automatically guarantees local compliance.

The enforcement record in the UAE is mixed [4]. The assessment of the country's enforcement is fraught with limitations, leading to inconclusive perceptions about the state of export controls. For instance, from 2006, the UAE came under pressure from the United States. The issue related to a container on transit to Iran which was suspected to be carrying aluminum sheeting originating from the US.

\section{The Case of the UK}

Exports control is a worldwide issue given the weight the UN accords the subject. The UK laws on export controls are derived from the kingdom's international obligations and commitments as well as national interests. In this regard, reference is made to the treaties and laws that the UK has embraced.

The UK ranks as the $11^{\text {th }}$ largest exporter of merchandise globally [4]. Additionally, the kingdom is the fifth biggest importer of goods. Historically, the nation has led in selling arms since it was the $6^{\text {th }}$ largest exporter of conventional weapons based on value between the period between 2008 and 2012. Based on figures from the UK government, the country is the 2nd largest seller of defense-related items and the $5^{\text {th }}$ biggest exporter of security products. Thus, the security and defense industries play a significant role in driving growth as well as innovation. The sectors also contribute to the creation of jobs to the country's nationals. Industry players from the UK have developed many surveillance applications that have been used in various parts of the world.

The UK is involved in efforts aimed at doubling its current exports to one trillion British pounds by the year 2020. The strategy heavily focuses on security and defense exports. The nation has emphasized the expansion of exports because it enjoys a comparative advantage in the field of technology. In 2012, the defense exports amounted to 11 billion pounds. The figure demonstrates a significant increase given that in the previous year, the country had generated 8 billion pounds [4]. During the same period, security exports grew by four percent to settle at 3 billion pounds.

The country's export control system has capacity given that the infrastructural facilities necessary are available. The platform revolves on UK's high level of security and defense exports. The system demonstrates robustness in terms of legislation as well as enforcement. At the international level, the UK has also played a significant role, having led calls for global frameworks to promote the control of the export of sensitive products. For instance, the UK was a leading sponsor of the Arms Trade Treaty, which it pushed through within the auspices of the United Nations.

Within the UK, licensed exports of dual-use and military goods are assessed based on a case-by-case merit against the criteria that is applied within the European Union Code of Conduct [12]. At the moment, a portion of the surveillance materials are under explicit licensing procedures. The idea that some surveillance equipments are not covered raises concerns about the universality of the application of the export control rules.

\section{International Arrangements}

The UK is party to the Treaty on the Non-Proliferation of Nuclear Weapons. The pact is traced to 1968 when the five official nuclear states (USA, France, Russia, UK, and China) committed to restrict the transfer of nuclear technology or weapons to other countries [13]. The states also pledged to avoid extending any form of assistance bordering on the acquisition of nuclear capability. Signatories to the treaty also endeavored to monitor the acquisition or attempts to develop nuclear weapons.

Subsequently, the UK was among the pioneering states that advanced the adoption of the Biological and Toxin Weapons Convention in 1975 [14]. The agreement disallowed the development, production, stockpiling, acquisition, and use of biological weapons. The pact also emphasized that the International Atomic Energy Agency to be allowed the powers to carry investigations into 
suspected proliferation activities.

The other important law that was adopted was the Chemical Weapons Convention that came into operation in 1997 [11]. The agreement bars countries from possessing, developing, producing, stockpiling, acquiring and using chemical weapons. Under the treaty, whenever production facilities are found in unauthorized countries, they must be destroyed.

The UK is also a party to a number of international regimes that regulate exports into the kingdom [11]. The establishments are critical in complementing the above legally binding treaties. The UK works with like-minded nations in fighting against the threat posed by proliferation. In this regard, reference is made to the role of the UK In developing lists of items and technology viewed as contributing to the proliferation problem.

The main groups focusing on regulating exports are the Australia Group (AG), Missile Technology Control Regime (MTCR), Zangger Committee (ZC), and the Wassenaar Arrangement (WA). The AG guidelines have been in operation for a number of years. The procedures relate to the export of chemicals and biological material that can be used in the production of harmful products. From 1985, countries including the UK have met regularly to discuss chemical and biological weapons. The UK has a detailed list of items that are regulated under the agreement. The list is found at the UK Strategic Export Control Lists. In addition, the UK applies guidelines on the End-Use Control provisions.

The Missile Technology Control Group concentrates on the regulation of rockets, missiles and related items. In particular, the regime guides products intended for military use. As early as 1987, the UK, USA, France, Canada, Japan, Germany, and Italy reached an agreement to establish rules to guide the exportation of missiles and related technology [15]. Ever since, membership into the regime has increased significantly.

Originally, the signatories of the regime were interested in controlling the transmission of technology or equipment that would contribute to the development of cruise or ballistic missiles. Having grown increasingly concerned about the proliferation of unidentified aerial vehicles and missiles, the group sought to extend its scope. Although the above agreement is not legally binding, the partners have voluntary committed to observe the provisions on exports. The pact is somewhat ambiguous given that it does not list any punishment on violations nor does it give details on enforcement. In attaining its control of export objectives, the UK ties the enforcement of the regime to guidelines on weapons of mass destruction end-use control or the military end-use control [15].

The UK is also a member of the Nuclear Suppliers Group, which came into existence in 1975. At the time, the international community was concerned about the regulations surrounding the supply of nuclear goods. In 1978, UK and members agreed to lower the chances of transferring goods from one use to another [16]. The guidelines cover high-risk goods only. The UK has detailed Trigger List requirements which oversee trading in dual-use or sensitive items.

The Wassenaar Arrangement is also one of the regimes that the UK subscribes to, in reference to controlling exports. The agree- ment came into operation in 1996 with the objective of increasing international stability and security [16]. This would be obtained through transparency, and acting responsibly when handling transfers of sensitive goods and technologies. The UK has implemented the arrangement by the enactment of the Export Control Order of 2008. The controls from the Wassenaar Arrangement agreements have been incorporated into the Strategic Export Control Lists of the UK.

The Zangger Committee was established in 1971 with the main objective of interpreting the obligations of the Treaty on the Non-Proliferation of Nuclear Weapons. Thus, the purpose was to control materials or equipment which designed and intended for nuclear use. The committee drew detailed lists on source or fissionable material to be controlled by countries [16]. The UK has adopted the regulations of the committee in its bid to coordinate and control the supply of nuclear items. When export goods of this nature within the UK, those involved are required to observe the material and technology \& the export of nuclear equipment, popularly known as the Trigger List' requirements. In addition regulations on weapons of mass destruction end-use control and military end-use control must be respected [11].

\section{UK Export Control Framework}

The statutory law regarding export control in the country is derived from the European Union and UK national legislation. Basic UK legislation concerning export controls falls into the 2002 Export Control Act. The law is subject to amendments out of secondary legislation as orders. The most notable alteration of the Act came in 2008 under the 2008 Export Control Order. The UK is also directly subject to UN Resolutions, international agreements, and treaties although legislation rests on parliamentary statutory laws.

The Consolidated List of Strategic Military and Dual-Use Items demand that Export Authorization show details of specific technology, goods, or assistance being shared between or among states [17]. In the event that an exporter is interested in exporting a service/product that is found in the consolidated list of sensitive goods, he/she must apply for an export license. Such an application is assessed based on the UK policy and the consolidated list to determine the export criteria. It is noted that the consolidated list takes into consideration the export of dual-use and military products, the Consolidated EU and National Arms Export Licensing Criteria.

The overall responsibility of regulating exports rests with the Department of Business, Innovation and Skills. As envisaged by the Export Control Act 2002, the secretary of the agency imposes legislation on sensitive goods. Within the department, the Export Control Organisation (ECO) is tasked with the responsibility of processing license applications, negotiating policies on export control on behalf of the kingdom, and initiating export licensing laws after consulting with other departments. For instance, the Ministry of Defence (MoD), the departments of Foreign and Commonwealth Office (FCO) and the Department for International Development can be consulted regarding license applications and technical intelligence on enforcement of control guidelines. It is noted that Her Majesty's Revenue \& Customs department is in charge of enforcing export controls using the customs network to identify breaches. 
Exporters are free to apply for various licenses. Generally, the most distinguished issue is about the restrictions attached to licenses. Typically, licenses specify the type and amount of product that can be exported.

\section{The Consolidated Criteria}

The United Kingdom evaluates applications concerning exporting items found in the Consolidated List and that approved under the EU Code of Conduct [15]. As per the provisions of the UK Consolidated Criteria, the likely effect of the exports on the country's defense and security interests, and those of ally countries are to be accounted for.

Based on the UK's Consolidated Criteria, the country's commercial and financial interests, and its association with the recipient country, and the consequence of the export with reference to the protection of the UK's strategic base assume significance when assessing exports.

\section{List-based Controls}

The UK Military List draws on the terms that appear on the EU Common Military List that is critical in defining the equipment covered under the EU Common Position [11]. For instance, countries belonging to the union (UK included) agreed to change the Wassenaar Munitions List in 2011. In the following year, the UK enforced the guidelines. The UK's Schedule 3 as referenced in Articles 2, 4 AND 5 of the Export Control Order 2008 is critical in the evaluation of Dual-Use goods. The country also has unilateral measures on given dual-use items. On several occasions, the UK has applied Article 8 drawn from the EU in assessing several goods such as technological and communication products. Under the UK Security and Human Rights List, reference is made to the position of the country which disallows exports of legirons, portable electric shock appliances, gang chains and licensing guidelines on items that appear on sensitive goods' lists [11]. The legislative basis of the UK draws on Article 9 of the Export Control Order of 2008.

In a bid to operationalize the controls, the government of the UK by-passed the EU Commission by imposing unilateral controls having established an individual list. For instance, the country created the Export of Radioactive Sources Order to reign on the trading of explosives as provided for under the Export Control Act of 2002 [18]. The same law aligns with the expectations of the Schedule of the Act. Under the latter guideline, export controls can be imposed on any item if its exportation or use has the capacity to undermine the country's security or that of other states. The same applies if the goods pose a risk to regional stability or threaten to trigger internal conflict. If the items involved are weapons likely to cause mass destruction or they breach international laws, then the law empowers the authorities to disallow exportation of such goods. The provisions also relate to terrorism/ crime goods or objects of cultural value.

The explanatory memorandum released with the Order of 2006 reflects that the imposition of unilateral controls was necessary given that the reliance on a broad policy such as the one emanating from the UK would be complex and difficult to execute. The UK was also seeking to allow for self-regulation and guarantee certainty in its operations.
Within the UK, an export can be subjected to authorization and prohibition when end-use of the item in question does not appear in the Consolidated List [18]. In the country, export controls bordering on end-use allow the authorities to bar exportation of dual-use or military goods whenever risks are involved or a potential exists that the products can be used to perpetuate mass destruction. The rule is adopted under the guise by the UK that it has the right to institute all types of control in suspicious cases. The laws are largely known as 'Catch-all Controls.' Thus, the UK has proactive measures that allow for the restriction of exports even when the items involved do not fall into the categories of the listed items. The arms control and counter-proliferation divisions of the UK government are in charge of implementing the measures. For example, the UK Restricted Enforcement Unit unifies the MoD, the GCHQ, the FCO, the MI5 and the MI6 in bi-weekly reviews of intelligence on exports of the above nature.

\section{UK Export Controls on Surveillance Technology}

The UK implements measures on surveillance technology largely because of its membership to the EU and the Wassenaar Dual-Use list established in 2011. For goods that are in the Ml11, attempts were being made to prevent the sale of software that would potentially be used to perpetuate warfare. Surveillance equipment is under the scope of UK export controls based on the addition of items to the preexisting lists [10]. The authorities have the power to apply sanctions or use provisional measures to guard against trade in dangerous goods. The addition of items into existing lists is done using many approaches. Given that the UK is a member of many international bodies, whenever any agency reviews its lists, the UK is affected. Thus, changes in such international lists automatically lead to alterations to the UK lists.

Under the Export Control of 2002, the UK has the ability to exercise emergency powers aimed at imposing restrictions issued at short notices. In particular, Section 6 gives authority regarding the imposition of controls when the control order specifies expiry dates. The power has been applied to cases involving human rights issues such as in 2010, when it was used in the establishment of an Order. The regulation was geared towards controlling lethal injections sold to the US.

Currently, the UK government does not pursue bilateral restrictions given that it views such arrangements as ineffective [11]. The country alleges that the possibility of circumventing the agreements is high. Hence, there is no need of putting in concerted efforts without any guarantee of success. On the contrary, having agreements with entities or agencies that bring together many states is seen as the most appropriate. A multilateral push serves the interests of export control better than bilateral ones simply because of the difference in membership numbers.

It is evident that the two countries are focused on controlling exports of items viewed as sensitive. One of the initial finding is that in the UAE, no lists exist while within the UK, a number of lists are available. Such include the Strategic Export Control List compiled based on the EU and UK laws. Some of them include: UK Military List (Schedule 2 of the Export Control Order 2008), the UK Dual-Use List (Schedule 3 of the Export Control Order 2008) and the UK National Security and Paramilitary List (Article 9 of Export). 
However, according to Maurer, Omanovic and Wagner, in the $\mathrm{UK}$, the list-based control system is commonly used. Some of the most significant lists include the UK Military List, the EU DualUse List, and the EU Human Rights List. The UK Military List draws on items that are identified by the EU Common Military List which defines the goods that are covered. Changes were also to be effected into the list following the reviewed of the Wassenaar Munitions List which was approved in 2011.

Regarding the Dual-Use List, the UK derives the goods on the basis of Article 2, 4, and 5 of the third Schedule of the Export Control Order 2008. Unilateral controls also apply to the UK based on Article 8 of the EU-Dual-Use Regulation and Export Control Order Section 3 (64). Under the section, the UK has focused on telecommunication equipment exports.

Concerning the EU Human Rights List, the UK relies on the EU Torture Regulation (66). The UK Security and Human Rights List captures nationally regulated items as outline under Article 7 of the EU Torture Regulation. The provision allows member countries to impose individual national guidelines on given equipment.

The UK also has the Export of Radioactive Sources Order which was made in reference to the provisions of the Export Control Act 2002 as outlined in section 1, 5 and 7. The guidelines are also in compliance with the subsection 1 of the second paragraph of the Act's Schedule. The latter allows the state to impose any regulations on any items that threaten national security or defense.

\section{Selected UK Orders/Articles}

Within the UAE, the UAE federal law No. 13 of 2007 and No. 12 of 2008 are the primary legislations that guide export control within the country. On the other hand, within the UK, the Export Control Act 2002, which came into force in 2004, is the main law regulating exports. The laws primarily apply to dual-use ad military items. The Export Control Act 2002 replaced the Import, Export and Customs Powers (Defence) Act 1939 with a view to enhancing transparency and accountability. Since its inception, the Act has preceded the introduction of secondary legislation to reign on exports. Just as in the case of the UAE federal law No. 13 of 2007, the Export Control Act 2002 has been amended to suit the changing environment. Among the orders that have been introduced previously include:

1. "Export of Goods, Transfer of Technology and Provision of Technical Assistance (Control) Order 2003 or 'Main Order'

2. Trade in Goods (Control) Order 2003

3. Trade in Controlled Goods (Embargoed Destinations) Order 2004

4. Technical Assistance Control Regulations 2006"

The Trade in Goods (Control) Order of 2003 accords powers to the Secretary of State to play a role in the regulation of the supply and delivery of restricted items. The third section of the Order indicates, "Subject to the provisions of this Order, no person shall directly or indirectly - (a) supply or deliver; (b) agree to supply or deliver; or (c) do any act calculated to promote the supply or delivery of, any restricted goods, where that person knows or has reason to believe that his action or actions will, or may, result in the removal of those goods from one third country to another third country."
In section 4, the Order relates to the transfer and acquisition of controlled products. The law states, "Subject to the provisions of this Order, no person shall - (a) arrange the transfer of controlled goods from one third country to another third country; or (b) acquire or dispose, or agree to acquire or dispose, of any controlled goods, where that person knows or has reason to believe that such an acquisition or disposal will or may result in the removal of those goods from one third country to another third country."

The above Order also delves into the licensing issue. On the matter, the law states, "Any license granted under this Order, shall be in writing and may be amended, suspended or revoked by the Secretary of State at any time and in such circumstances and on such terms as he thinks fit by serving a notice to that effect on the holder of the license".

When reviewing the Export of Goods, Transfer of Technology and Provision of Technical Assistance (Control) Order 2003, reference is made to Article 4. Article 4 of the 2002 Export Control focuses on the issue of end-use control and dual-use goods. Subsection one of the article states, "Subject to the provisions of this Order, goods of a description specified in Schedule 2 to this Order are prohibited to be exported to the destinations specified in that Schedule as being prohibited destinations in relation to those goods."

In the present time, some orders are in place to control trade on dual-use and military goods. Following amendments carried out in 2007 and 2008, the above orders were consolidated into the Export Control Order. Thus, the Export Control Order 2008 is the major law regulating trade in strategic products, transfer of technology and extension of technical help. The legislation also applies to trade in dual-use or sensitive goods among countries. Reference is also made to trade with countries subject to international sanctions.

Since its inception, piecemeal changes have been made with the aim of updating the control lists. Additionally, the legislation puts checks on the export of radioactive substances as indicated in the Export of Radioactive Sources (Control) Order 2006.

The UK makes the following provisions based on its 2202 ACT. The first schedule captures dual-use and military items.

“(1)Export controls and trade controls may be imposed in relation to -

(a) military equipment;

(b) goods on which military technology is recorded or from which it can be derived; or

(c) goods intended, designed or adapted for use in the development or production of military equipment or military technology."

The above items demonstrate that the laws of the two countries are unified in terms of the category of goods targeted for control. It is also remarked, "The Secretary of State may by order make provision for or in connection with the imposition of export and controls in relation to goods of any description.” In clarifying the clause, the Act indicates that any goods imply pro-biting the regulating exportation from the UK or shipment. 
Under section 2 of the UK Act, the focus is on transfer controls. The article states, that "the Secretary of State may by order make provision for or in connection with the imposition of transfer controls in relation to technology of any description." The provision further clarifies that no individual from the UK can handle proscribed technology transfer from the country to another destination and vice versa. In describing technology, the Act states that, "Technology may be described in the order wholly or partly by reference to the uses to which it may be put."

The third section is on the issue of technical assistance. Subsection 4 of the Act indicates, "The power to impose technical assistance controls shall only be exercised for the purpose of imposing controls corresponding to or connected with any export controls or transfer controls". Thus the implication is that controlling technical assistance which falls into the technology category is a matter of interest to both countries.

Article 8 of the Dual-Use Regulation permits extending controls to non-listed items. The justification for the unlimited nature of the provision is meant to secure the country. In particular, internal security and human rights considerations are major points considered by the country.

The UK is bound by the decisions on exports control as a member of the European Union. In particular, the EU Restrictive Measures on surveillance and monitoring applies to the country. Reference to sanction and embargo regimes by the EU assume significance when reviewing the UK. Such measures are implemented as per the directions of the Common Foreign and Security Policy platform.

The UK has also embraced the Torture Regulations as advanced by the EU. Regulation No. 1236/2005 focuses on restrictions on trading in specific goods whose use can perpetuate torture, capital punishment, or cruel treatment. Imposed behind the backdrop of the European Union law, the regulation applies to all members of the union, and requires them to review items listed to be under control continuously.

\section{Recommendation}

In order to increase the chances of realizing the expectations of export controls, patience will be required in the case of the UAE since establishing an effective system takes time. Hence the Commodities Subject to Import and Export Controls needs to take a deliberate approach to achieve the objectives that associated with the measures it is undertaking currently. The country should consider developing new regulations, processes and reinforce its competences on the administration and implementation of export control regulations. Given that the regulatory regime is relatively new, patience is necessary. Although it is possible to make steady progress, taking an incremental approach would be the most appropriate approach given the prevailing circumstances. The authorities should also avoid working to the whims of western powers because the development of export controls should take into account the long-term goals of the country.

It is apparent that the UAE would benefit from importing the required expertise to control exports. However suing indigenization would also be helpful. The authorities should ask international bodies or developed states such as the US to provide support to the local agencies regarding the fight against trade in sensitive items.

\section{Observations}

In summary, the following observations have been made. The issue of discretion has also emerged as a common aspect of the countries' laws. Article 2 of Federal Law No. 12 of 2008 allows the authorities wide discretionary power. Based on the article, the UAE accords state authorities the power to control items entering or exiting the country. The article is closely related to the 'Catchall Controls' in the UK which also grants authorities the power to assess goods and determine if they pose a risk to the country before taking appropriate action.

It also emerges that besides establishing national laws to oversee export control in the countries, efforts have been made to work with other nations. This is achieved by taking part in entities that bring together a number of countries to fight illicit trade. In this regard, reference is made to the number of international arrangements that the two countries are part of. The UAE has ratified an array of initiatives and treaties which influence trade in strategic commodities. It has signed pacts on nuclear, biological and chemical, missile, terrorism and proliferation. Furthermore, the country has also ratified deals regarding terrorism. The UAE is a signatory of the Container Initiative, the Security Freight Initiative, and the Megaports Initiative. The country has also approved the Proliferation Security Initiative. Besides, the UAE is a member of the Comprehensive Nuclear-Test-Ban Treaty and the Non-Proliferation Treaty, which bring together states, arrangements bringing together states against nuclear weapons proliferation.

From the paper, it is also noted that the UK takes part in a number of international initiatives with the intention of controlling exports. For instance, the UK is a leading member of the Wassenaar Arrangement. Other arrangements include the Treaty on the Non-Proliferation of Nuclear Weapons, the Biological and Toxin Weapons Convention and the International Atomic Energy Agency, among others. However, the UAE is not a member of the Australia Group (AG) or the Nuclear Suppliers Group (NSG). This contrasts with the UK, which is an active member in both bodies.

Control lists are integral to the fight against illegal exports. The UAE does not have a list while the UK has a number of such lists. Hence, the UAE has ground to cover towards succeeding on the fight against proliferation.

The two countries laws capture the issue of radioactive substances too. For the UAE, reference is made to Article 25, which accords FANR the responsibility of regulating materials entering or exiting the country. The legislation also extends to nuclear fuel, and related materials. In a bid to operationalize the controls, the UK imposes unilateral controls having established an individual list based on the Export of Radioactive Sources Order to as envisaged under the Export Control Act of 2002.

\section{Conclusion}

Export controls can prove effective as tools of protecting the 
world from abuses that emerge from trading on sensitive or dangerous products. Given that the world landscape keeps changing, the export control system also needs to be changed in order to keep pace with the developments. Updating the export control system would be a major step in enhancing the control platform. Adopting sound implementation policies would also be important in improving the effectiveness of export control systems. Such frameworks need to include well-defined evaluations criteria, reporting and enforcement requirements.

From the comparison, it is evident that the frameworks are also broad. Hence, narrowing them down would be important in enhancing their effectiveness. In practice, a wide reference model is difficult to implement owing to the complexities that accompany them. As argued in the case of the UK, entering multilateral arrangements provides a platform that is more likely to lead to a positive outcome in the pursuit of export controls. As opposed to unilateral or bilateral decisions, multilateral arrangements enjoy the support of many players, hence are more likely to attain better results.

The wider security and defense sectors need to engage in developing more effective export controls. This would provide clarity and ensure that deceptive actors do not gain control of the industry.

\section{References}

[1]. Bryan RE. Export Control Development in the United Arab Emirates: From Commitments to Compliance. Cambridge: Harvard Kennedy School; 2009.

[2]. Douglas MS, Bryan RE, Cale H, Johannes K. Complying by Denying: Ex- plaining Why States Develop Nonproliferation Export Controls. Athens, GA: The University of Georgia; 2009.

[3]. McGovern E. Export Controls in the United Arab Emirates: A Practical Manifestation of a Strategic Dilemma. WMD Insights. 2009 Feb;30:12-3.

[4]. Bergenäs J. The Slippery Slope of Rational Inaction: Resolution 1540 and the Tragedy of the Commons. Nonproliferation Review. 2008 Jul 1;15(2):37380 .

[5]. Fuhrmann M. Making 1540 work: achieving universal compliance with nonproliferation export control standards. World Affairs. 2007 Jan 1;169(3):143-52.

[6]. Horner D. UAE's Regulator Recognizes Need for Emirati Staff, Chief Says. Nucleonics Week. 2009 Mar 19:1.

[7]. Beck MD, Cupitt RT, Jones SA, Galhaut S. To Supply or to Deny: Comparing Nonproliferation Export Controls in Five Key Countries. Kluwer Law International BV; 2003.

[8]. Federal Law No. 12 of 2008.

[9]. Export Control Act. UK Government; 2002.

[10]. UK Ministry of Defence. National Security through Technology: Technology, Equipment, and Support for UK Defence and Security. Surrey: Crown Copyright; 2012.

[11]. Maurer T, Omanovic E, Wagner B. Uncontrolled Global Surveillance: Updating Export Controls to the Digital Age. New America Foundation; 2014.

[12]. United Kingdom, Customs: The Export Control (Amendment) (No. 3) Order, Statutory Instrument, 2010.

[13]. Valentino-Devries J, Angwin J, Stecklow S. Document trove exposes surveillance methods. The Wall Street Journal. 2011 Nov 19;19.

[14]. UK Department for Business, Innovation \& Skills. Consolidated EU and National Arms Export Licensing Criteria. 2012.

[15]. Mark B. The Review of the EU Common Position on Arms Exports: Prospects for Strengthened Controls. EU Non-Proliferation Consortium; 2012.

[16]. United Kingdom, Customs: The Export Control Order 2008, Statutory Instrument, 2008 No. 2231. 2008.

[17]. Committees on Arms Export Controls, UK Parliament, Scrutiny of Arms Exports and Arms Control Annex 3. 2013.

[18]. United Kingdom, Explanatory Memorandum to the Export of Radioactive Sources (Control) Order 2006 No.1846. 2006. 